\title{
COMPOSITION AND BIOMEDICAL RELEVANCE OF SEA BUCKTHORN
}

\author{
ANNA JASTRZĄB* and ELŻBIETA SKRZYDLEWSKA
}

\begin{abstract}
Departament of Inorganic and Analytical Chemistry, Medical University of Bialystok, Mickiewicza 2D, 15-222 Białystok, Poland
\end{abstract}

\begin{abstract}
Sea buckthorn (Hippophae rhamnoides L.) is a plant belonging to the Elaeagnaceae family. It is widely distributed throughout Asia, and Europe, especially in colder regions. Generally, sea buckthorn species vary in their phytochemical composition, depending on the climate, and soils in which they grow. Sea buckthorn has been used in traditional medicine for centuries, due to its rich chemical composition. The leaves, fruits, and seeds of this plant are a rich source of bioactive compounds, such as vitamins (A, E, K, C, B1, B2), phenolic compounds (e.g gallic acid, catechin, quercetin, kaempferol), fatty acids (e.g linoleic acid, á-linolenic acid, palmitoleic acid, vaccenic acid), amino acids (e.g glycine, isoleucine, cysteine, tyrosine, histidine, arginine), micro-, and macroelements. The presence of a large number of bioactive compounds results in a broad spectrum of biological activity. It has been shown that sea buckthorn has antioxidant, and anti-inflammatory properties, moreover it protects, and regulates cellular metabolism, has cardioprotective properties, and protective effect on skin cells. Research from recent years offers the hope that sea buckthorn preparations will be used in the treatment of, for example, skin burns, atopic dermatitis or abnormal cholesterol levels, but also as a support for the treatment of, for example, cardiovascular diseases.
\end{abstract}

Keywords: sea buckthorn, sea buckthorn composition, biomedical activity, skin protection

Sea buckthorn (Hippophae rhamnoides L.; Elaeagnus rhamnoides (L.) A. Nelson) belongs to the Elaeagnaceae family, which naturally occurs in Asia, and Europe. There are seven basic species of sea buckthorn, but the exact number of subspecies is not specified. Depending on the climate, soil, and location, the different subspecies may differ in nutritional content (1-3).

Sea buckthorn is a branched shrub or a small tree that is up to 3-4 meters tall with soaring, lanceshaped silver-grey leaves. Ripe fruits (berries) of sea buckthorn are orange-red. Inside the fruit, in addition to the soft inner tissue, there is a single dark brown seed in the central part of the fruit. All parts of the plant contain about 200 bioactive components, including flavonoids, phenolic compounds, tocopherols, fatty, and organic acids, fats, vitamins (A, E, K, C, B1, and B2), amino acids, terpenes, tannins, and macroelements (2).

\section{Leaves}

Sea buckthorn leaves contain many bioactive and nutritious compounds, including flavonoids, carotenoids, sterols, and triterpenes. Moreover, they are a rich source of potassium, magnesium, and cal- cium (4). The concentration of individual biologically active compounds in the organic extracts from sea buckthorn leaves depends on both the subspecies of sea buckthorn and the location of its occurrence (5-7). Due to their biological importance, phenolic compounds deserve special mention, especially such as myricetin or isorhamnetin (which have a total concentration ranging from 76.07 to $93.72 \mathrm{mg} / \mathrm{g}$ of dry material) as well as flavonoids (from 47.06 to $66.40 \mathrm{mg} / \mathrm{g}$ of dry matter). From the leaves of sea buckthorn, it is possible to obtain essential oils, which mainly consist of organic acids (constituting at least $36 \%$ of all compounds (Table 1) (8).

\section{Fruits, and seeds}

Like the sea buckthorn leaves, the fruits, and seeds have also been examined for their chemical compositions. They are characterized by a high content of phenolic compounds, fatty acids, tocopherols, and tocotrienols (Tables 2-5), whereas the level of individual components depends on the subspecies of sea buckthorn, and environmental factors such as the type of soil, climate, etc. The chemical compositions of sea buckthorn fruits and seeds are similar to those of the leaves. (9-16). However, oil

* Corresponding author: e-mail: anna.jastrzab@umb.edu.pl 
Table 1. Percentages of organic compounds that are present in the essential oils obtained from the leaves of sea buckthorn (8).

\begin{tabular}{|c|c|}
\hline Acids & $\mathbf{3 6 . 7 0 \%}$ \\
\hline n-hexadecanoic acid & $26.07 \%$ \\
\hline oleic acid & $6.73 \%$ \\
\hline tetradecanoic acid & $3.90 \%$ \\
\hline Esters & $\mathbf{1 8 . 1 5 \%}$ \\
\hline dibutyl phthalate & $7.37 \%$ \\
\hline 8,11 -octadecadienoic acid, methyl ester & $3.49 \%$ \\
\hline stearicacid, ethyl ester & $2.51 \%$ \\
\hline Alkanes & $\mathbf{1 1 . 0 4 \%}$ \\
\hline Ketones & $\mathbf{1 8 . 4 9 \%}$ \\
\hline Other compounds & $\mathbf{1 . 6 5 \%}$ \\
\hline
\end{tabular}

Table 2. Average concentrations of phenolic compounds contained in sea buckthorn fruits (9).

\begin{tabular}{|c|c|c|c|c|c|c|}
\hline \multirow{3}{*}{$\begin{array}{l}\text { Phenolic compound } \\
\text { Phenolic acids }\end{array}$} & \multicolumn{5}{|c|}{ (mg/100 g dried fruit weight) } & \multirow[t]{2}{*}{ Total content } \\
\hline & GA & PA & FA & - & - & \\
\hline & 19.8 & 39.3 & 3.76 & - & - & 62.9 \\
\hline \multirow[t]{2}{*}{ Flavones } & $\mathrm{CE}$ & Epi & QE & KA & IS & \\
\hline & 8.99 & 2.14 & 5.51 & 1.23 & 13.1 & 30.9 \\
\hline \multirow[t]{2}{*}{ Flavmonoglycosides } & Q3R & Q3G & I3R & I3G & - & \\
\hline & 32.9 & 39.7 & 58.6 & 15.5 & - & 147 \\
\hline \multirow[t]{2}{*}{ Flavdiglycosides } & K-3-S-7-Rh & I-3-S-7-Rh & I-3-G-7-Rh & - & - & \\
\hline & 45.0 & 39.7 & 148 & - & - & 233 \\
\hline
\end{tabular}

Abbreviations: GA-gallic acid, PA-protocatechuic acid, FA-ferulic acid, CE-catechin, Epi-epicathin, QE-quercetin, KA-kaempferol, ISisorhamnetin, Q3R-quercetin-3-rutinoside, Q3G-quercetin-3-glucoside, I3R-isorhamnetin-3-rutinoside, I3G-isorhamnetin-3-glucoside, K-3-S-7-Rh-kaempferol-3-sophoroside-7-rhamnoside, I-3-S-7-Rh-isorhamnetin3-sophoroside-7-rhamnoside, I-3-G-7-Rh-isorhamnetin3-glucoside-7-rhamnoside

extracted from sea buckthorn pulp is a rich source of palmitic, and vaccenic acids, while seed oil has a high content of linoleic, $\alpha$-linolenic, and oleic acids (13). The amount of vitamin $C$ that is contained in sea buckthorn fruits ranges from $56 \mathrm{mg} / 100 \mathrm{~g}$ to a massive $3909 \mathrm{mg} / 100 \mathrm{~g}$ (14) (from 25 to 166 $\mathrm{mg} / 100 \mathrm{~mL}$ of juice) (15), whereas the vitamin $\mathrm{E}$ content in fruit juice ranges from 1.33 to 255 $\mathrm{mg} / 100 \mathrm{~g}$, and in seeds, and oil, from 40.1 to 113 $\mathrm{mg} / 100 \mathrm{~g}$. Also, sea buckthorn also contains vitamin $\mathrm{K}$, the content of which ranges from 100 to 230 $\mathrm{mg} / 100 \mathrm{~g}$ in fruit, and juices, while in seeds, and oils, it ranges from 110 to $230 \mathrm{mg} / 100 \mathrm{~g}$ (16-18).

Sea buckthorn fruits are a rich source of carotenoids and their esters. Twelve compounds from this group have been identified, with the largest concentration being zeaxanthin $(81.29 \mathrm{mg} / \mathrm{g}$ dried fruit weight), ß-carotene (15.19 mg/g dried fruit weight), and astaxanthin $(11.94 \mathrm{mg} / \mathrm{g}$ dried fruit weight); the lowest concentration include lycopene $(2.24 \mathrm{mg} / \mathrm{g}$ dried fruit weight $)(3,19)$. In addition to the presence of carotenoids, some sterols were identified in sea buckthorn fruits, and oil, including campesterol, $\beta$ sitosterol, and stigmasterol (Table 6) $(3,17,20)$.

It has also been shown that sea buckthorn fruit is an excellent source of amino acids (Table 7), as well as micro- and macroelements. The contents of individual amino acids are variable, and they depend on the source of sea buckthorn. However, these elements are present in significant quantities, so that the consumption of fruits or juices from sea buckthorn can be used as a form of dietary supplementation for certain elements that are necessary for the proper functioning of the body $(18,21,22)$. 
It is possible to obtain juices from sea buckthorn berries, with up to $75 \%$ of the vitamin $\mathrm{C}$ being contained in the fruit pulp (19). Additionally, the raw sea buckthorn juice contains insignificant amounts of oil, which may represent between 3-4\% of the total weight of the juice (23). The seeds, and fruit pulp can be used to obtain oil, because the oil content in the ripe seeds can range from $8-20 \%$ (w/w), and from $20-25 \%$ in whole dried fruits (flesh, and skin), while residues from the fruit after juice-pressing contain $15-20 \%$ oil (22).

Table 3. Phenolic acid content in sea buckthorn fruit (average content and content range are based on data obtained for six varieties) (10).

\begin{tabular}{|c|c|c|c|c|}
\hline & \multirow[t]{2}{*}{ Components } & Free phenolic & $\begin{array}{c}\text { Phenolic and related } \\
\text { acids acids liberated } \\
\text { from esters }\end{array}$ & $\begin{array}{c}\text { Phenolic and related } \\
\text { acids liberated from } \\
\text { glycosides }\end{array}$ \\
\hline & & \multicolumn{3}{|c|}{ (mg/kg dried fruit weight) } \\
\hline \multirow{10}{*}{$\begin{array}{l}\text { Hydroxybenzoic } \\
\text { acid derivatives }\end{array}$} & 2,5-Dihydroxybenzoic & $\begin{array}{c}1.8 \\
(0.1-6.1)\end{array}$ & $\begin{array}{c}40.7 \\
(10.8-79.3)\end{array}$ & $\begin{array}{c}7.5 \\
(0.3-20.7)\end{array}$ \\
\hline & Gallic & $\begin{array}{c}2.0 \\
(1.0-4.6)\end{array}$ & $\begin{array}{c}552.7 \\
(146.3-1008.0)\end{array}$ & $\begin{array}{c}69.9 \\
(51.0-113.7)\end{array}$ \\
\hline & p-Hydroxybenzoic & - & $\begin{array}{c}12.7 \\
(3.7-20.0)\end{array}$ & - \\
\hline & Pyrocatechuic & $\begin{array}{c}2.3 \\
(0.8-6.3) \\
\end{array}$ & $\begin{array}{c}14.7 \\
(0.2-32.1) \\
\end{array}$ & $\begin{array}{c}4.1 \\
(3.3-5.2)\end{array}$ \\
\hline & Protocatechuic & $\begin{array}{c}2.1 \\
(0.7-4.3) \\
\end{array}$ & $\begin{array}{c}99.1 \\
(54.6-125.0) \\
\end{array}$ & $\begin{array}{c}14.2 \\
(7.9-21.3) \\
\end{array}$ \\
\hline & 3,4-Dihydroxycinnamic & - & $\begin{array}{c}17.8 \\
(5.9-27.3) \\
\end{array}$ & - \\
\hline & Salicylic & $\begin{array}{c}33.5 \\
(21.0-47.5)\end{array}$ & $\begin{array}{c}1368.2 \\
(1004.1-1726.4)\end{array}$ & $\begin{array}{c}1086.5 \\
(899.5-1524.1)\end{array}$ \\
\hline & Syringic & - & - & $\begin{array}{c}5.8 \\
(2.5-12.8) \\
\end{array}$ \\
\hline & Vanillic & $\begin{array}{c}1.0 \\
(0.5-1.8)\end{array}$ & $\begin{array}{c}8.1 \\
(0.8-16.4)\end{array}$ & $\begin{array}{c}6.4 \\
(1.4-8.4)\end{array}$ \\
\hline & Veratric & - & $\begin{array}{c}23.3 \\
(3.3-63.0)\end{array}$ & $\begin{array}{c}10.4 \\
(0.3-20.0)\end{array}$ \\
\hline \multirow{6}{*}{$\begin{array}{l}\text { Hydroxycinnamic } \\
\text { acid derivatives }\end{array}$} & Caffeic & $\begin{array}{c}4.1 \\
(0.9-6.6) \\
\end{array}$ & $\begin{array}{c}11.6 \\
(6.3-15.8) \\
\end{array}$ & $\begin{array}{c}7.2 \\
(1.3-10.0) \\
\end{array}$ \\
\hline & m-Coumaric & $\begin{array}{c}3.5 \\
(0.3-6.1) \\
\end{array}$ & $\begin{array}{c}38.2 \\
(18.1-86.4) \\
\end{array}$ & $\begin{array}{c}13.4 \\
(5.7-27.1) \\
\end{array}$ \\
\hline & o-Coumaric & $\begin{array}{c}6.3 \\
(2.2-13.3) \\
\end{array}$ & $\begin{array}{c}9.2 \\
(4.3-12.5) \\
\end{array}$ & $\begin{array}{c}15.8 \\
(6.3-26.6) \\
\end{array}$ \\
\hline & p-Coumaric & $\begin{array}{c}5.6 \\
(1.4-9.8) \\
\end{array}$ & $\begin{array}{c}144.1 \\
(90.3-290.8) \\
\end{array}$ & $\begin{array}{c}121.7 \\
(43.9-328.4) \\
\end{array}$ \\
\hline & Ferulic & - & $\begin{array}{c}11.7 \\
(5.1-17.8) \\
\end{array}$ & $\begin{array}{c}82.4 \\
(11.4-201.3) \\
\end{array}$ \\
\hline & Hydroxycaffeic & - & $\begin{array}{c}23.6 \\
(9.1-58.8) \\
\end{array}$ & $\begin{array}{c}12.1 \\
(1.3-22.3) \\
\end{array}$ \\
\hline \multirow{3}{*}{$\begin{array}{l}\text { Other phenolics } \\
\text { acids }\end{array}$} & p-Hydroxyphenyl-lactic & $\begin{array}{c}11.7 \\
(5.3-24.7)\end{array}$ & - & $\begin{array}{c}25.0 \\
(2.3-70.0) \\
\end{array}$ \\
\hline & Quinic & - & $\begin{array}{c}59.8 \\
(9.2-190.7) \\
\end{array}$ & - \\
\hline & Cinnamic & - & $\begin{array}{c}297.4 \\
(0.8-803.9)\end{array}$ & - \\
\hline \multicolumn{2}{|c|}{ Total content of phenolic acids } & $\begin{array}{c}72.1 \\
(51.9-99.2)\end{array}$ & $\begin{array}{c}2323.9 \\
(2020.8-2506.2)\end{array}$ & $\begin{array}{c}1452.7 \\
(1135.6-1868.8)\end{array}$ \\
\hline
\end{tabular}


It should be highlighted that the contents of individual biologically active compounds in fruit or seeds differ significantly from the contents of these compounds in other parts of the plant (Table 8) (23, 24).

\section{Roots, stems, and branches}

The roots, stems, and branches of sea buckthorn are not well-known with regard to biologically active compounds. Studies on the compositions of these plant parts have shown that they are an excellent source of phenolic compounds with a total content of 52 to $95 \mathrm{mg}$ GAE/g of dry extract (milligrams of gallic acid-equivalent per $1 \mathrm{~g}$ of dry extract) for stem extracts, while for root extracts this content ranges from 36 to $139 \mathrm{mg}$ GAE/g of dry extract (25). Sea buckthorn branches are also a source of phenolic compounds, because in alcohol extracts from the branches it was possible to extract and to identify (+)-catechine, (+)-gallocatechin, and (-)-epigallocatechin. (26) Moreover, ursolic acid, representing triterpenoids, was separated from ethanol extract, but for none of the mentioned chemical compounds, the exact content in the extracts obtained was determined (26).

Tannins were also found in the stem, and root extracts, over a range of 14 to $34 \mathrm{mg} \mathrm{CE} / \mathrm{g}$ dry extract (milligrams catechin-equivalent/g dry extract) for stems, and 16 to $42 \mathrm{mg} \mathrm{CE} / \mathrm{g}$ dry extract for roots. It was found that the stems and roots are also a source of amino acids and sugars, but their exact contents have not yet been determined (25).

\section{Biological activity of sea buckthorn Antioxidant and anti-inflammatory properties}

Extracts from sea buckthorn exhibit antioxidant properties, because they contain high concentrations of polyphenolic compounds $(5,7,25)$. The antioxidant properties of sea buckthorn extract were mostly measured in vitro, via reactions with DPPH, TBA, and FRAP. Extracts of sea buckthorn demonstrate the ability to capture free radicals according to

Table 4. Fatty acid content of sea buckthorn seeds, and sea buckthorn fruit pulp extracts $(11,12,13)$.

\begin{tabular}{|c|c|c|}
\hline \multirow{2}{*}{ Fatty acids } & Seed oil & Pulp oil \\
\cline { 2 - 3 } & \multicolumn{2}{|c|}{ (mass \% of total amount of fatty acid) } \\
\hline Palmitic $(16: 0)$ & $7.0^{(\mathrm{A})}-11.3^{(\mathrm{C})}$ & $33.4^{(\mathrm{C})}-35.2^{(\mathrm{A})}$ \\
\hline Palmitoeic $(16: 1 \mathrm{n}-7)$ & $4.4^{(\mathrm{C})}-9.80^{(\mathrm{B})}$ & $24.9^{(\mathrm{C})}-33.4^{(\mathrm{B})}$ \\
\hline Stearic $(18: 0)$ & $2.6^{\mathrm{AAB}, \mathrm{B})}$ & $1.0^{(\mathrm{C})}-1.5^{(\mathrm{B})}$ \\
\hline Oleic $(18: 1 \mathrm{n}-9)$ & $13.6^{(\mathrm{A})}-22.1^{\mathrm{a}(\mathrm{B})}$ & $3.3^{(\mathrm{A})}-26.2^{(\mathrm{C})}$ \\
\hline Linoleic $(18: 2 \mathrm{n}-6)$ & $29.1^{\mathrm{BB})}-35.5^{(\mathrm{A})}$ & $5.1^{(\mathrm{C})}-12.8^{(\mathrm{A})}$ \\
\hline$\alpha$-Linolenic $(18: 3 \mathrm{n}-3)$ & $23.4^{\mathrm{B})}-37.4^{(\mathrm{A})}$ & $1.5^{(\mathrm{A})}-2.3^{\mathrm{b}(\mathrm{B})}$ \\
\hline 11 -Octadecanoic $($ Vaccenic $)$ & $(18: 1 \mathrm{n}-7) 2.1^{(\mathrm{A})}-3.2^{(\mathrm{C})}$ & $6.9^{(\mathrm{A})}-73^{(\mathrm{C})}$ \\
\hline Nervonic $(24: 1 \mathrm{n}-9)$ & - & $1.3^{(\mathrm{A})}$ \\
\hline
\end{tabular}

(A) petroleum-ether extraction, (B) hexane extraction, (C) chloroform/methanol extraction; ${ }^{\text {a }}$ - content of oleic and vaccenic acids; ${ }^{\text {b }}-$ total content of $\alpha$ - and $\gamma$-linolenic acids

Table 5. Content of tocopherols, and tocotrienols in seed oil, and pulp oil $(11,14)$.

\begin{tabular}{|c|c|c|c|}
\hline \multirow{2}{*}{ Compounds } & Seeds & Fruit pulp & Fruits \\
\cline { 2 - 4 } & \multicolumn{2}{|c|}{$\begin{array}{c}\text { Petroleum-ether extraction } \\
(\mathrm{mg} / 100 \mathrm{~g} \text { of oil })\end{array}$} & $\begin{array}{c}\text { Melative } \\
\text { content }(\%)\end{array}$ \\
\hline$\alpha$-tocopherol & 223.4 & 143.7 & - \\
\hline$\beta$-tocopherol & 11.8 & 14.5 & 3 \\
\hline$\gamma$-tocopherol & 177.4 & 7.2 & 18 \\
\hline$\delta$-tocopherol & 8.0 & 5.3 & 5 \\
\hline$\alpha$-tocotrienol & - & - & - \\
\hline$\beta$-tocotrienol & 9.7 & 2.3 & - \\
\hline$\delta$-tocotrienol & - & 8.1 & - \\
\hline Plastochromanol-8 & - & & \\
\hline
\end{tabular}


Table 6. Sterols in the seed oil, and fruit pulp of sea buckthorn, and in the lipid fraction of sea buckthorn fruit extracts $(11,19)$.

\begin{tabular}{|c|c|c|c|}
\hline \multirow[t]{2}{*}{ Compounds } & Seeds & Fruit pulp & \multirow{2}{*}{$\frac{\text { Fruits (8 varieties) }}{(\mathrm{g} / 100 \mathrm{~mL} \text { lipid fraction })}$} \\
\hline & \multicolumn{2}{|c|}{$(\mathrm{mg} / 100 \mathrm{~g} \text { of oil })^{\mathrm{c}}$} & \\
\hline Cholesterol & 3.7 & 4.6 & - \\
\hline Campesterol & 22.4 & 12.4 & $\begin{array}{c}122.12 \\
(44.37-201.32)\end{array}$ \\
\hline Stigmasterol & - & 6.6 & $\begin{array}{c}46.15^{\mathrm{d}} \\
(24.08-68.24)\end{array}$ \\
\hline$\beta$-Sitosterol & 746.3 & 576.9 & $\begin{array}{c}3952,89 \\
(2036.14-6145.58)\end{array}$ \\
\hline Squalene & - & - & $\begin{array}{c}1496.08 \\
(885.71-27147.37)\end{array}$ \\
\hline Sitostanol & - & - & $\begin{array}{c}164.67 \\
(96.50-254.67)\end{array}$ \\
\hline$\Delta 5$-Avenasterol & - & - & $\begin{array}{c}238.30 \\
(114.93-377.56)\end{array}$ \\
\hline$\alpha$-Amyrin & - & - & $\begin{array}{c}196.21 \\
(110.48-314.52)\end{array}$ \\
\hline Cycloartenol & - & - & $\begin{array}{c}396.40 \\
(293.46-474.38)\end{array}$ \\
\hline$\Delta 7$-Avenasterol & - & - & $\begin{array}{c}151.44 \\
(80.80-194.97)\end{array}$ \\
\hline 28-Methylobtusifoliol & - & - & $\begin{array}{c}155.40 \\
(70.88-251.85)\end{array}$ \\
\hline 24-Methylenecycloartanol & - & - & $\begin{array}{c}2509.94 \\
(1454.21-4048.89)\end{array}$ \\
\hline Erythrodiol & - & - & $\begin{array}{c}491.51 \\
(284.02-818.75) \\
\end{array}$ \\
\hline Citrostadienol & - & - & $\begin{array}{c}361.16 \\
(212.97-663.22)\end{array}$ \\
\hline Friedelan-3-ol & - & - & $\begin{array}{c}424.62 \\
(257.16-737.28)\end{array}$ \\
\hline
\end{tabular}

${ }^{\mathrm{c}}$ The efficiency of obtaining oil from the seeds is about $4 \%(\mathrm{w} / \mathrm{w})$, while the efficiency of obtaining oil from the pulp is about $10 \%$ (w/w). ${ }^{\mathrm{d}}$ The range and the average of the contents, based on values obtained for two varieties of sea buckthorn

measurements with 1,1-diphenylo-2-picrylhydrazyl (DPPH) $(5,7,25)$, thiobarbituric acid (TBA) (5), and $\mathrm{Fe}^{3+}$ ions (FRAP) $(7,25)$ at similar levels, as measured for typical model antioxidants (butylated hydroxyanisole (BHA) and butylated hydroxytoluene (BHT)). Active compounds that are present in sea buckthorn may act as free-radical scavengers and inhibitors of lipid peroxidation $(5,7,25)$. This activity is due to its ability to quench singlet oxygen (5) and electron capture (25). Extracts from the seeds and the roots of sea buckthorn show higher antioxidant activities in comparison with the observed effects of leaf and stem extracts (25). Antioxidant activity was also confirmed in tests on animals. It was found that antioxidants (including flavonoids and vitamins) that are present in sea buckthorn leaf extracts show protective properties under in vivo conditions that are related to antioxidant enzymes, such as superoxide dismutase (SOD), catalase (CAT), glutathione peroxidase (GPX), glutathione reductase (GR), and glutathione-S-transferase (GST), which is present in the blood serum of rats treated with carbon tetrachloride (6). The extracts from different parts of sea buckthorn (butanolic extracts from twigs and leaves and berries phenolic extract) protect cells against the effect of oxidizing factors, such as hydrogen peroxide $\left(\mathrm{H}_{2} \mathrm{O}_{2}\right)$ or $\mathrm{H}_{2} \mathrm{O}_{2} / \mathrm{Fe}$. Moreover, it was shown that non-polar fraction containing triterpenes and their derivatives was more efficient in suppressing lipid peroxidation caused by $\mathrm{H}_{2} \mathrm{O}_{2} / \mathrm{Fe}$ than polar fraction rich in phenolic compounds $(27,28)$.

There is a link between the anti-inflammatory effects of sea buckthorn leaf extracts and a decrease 
in the level of nitric oxide, which is an inflammation marker. Nitric oxide levels were tested on the murine cells of the macrophages line RAW 264.7 (commonly used to evaluate the production of nitric oxide and the expression of induced nitric oxide synthase (iNOS)) (29), and in vivo tests on rats with injected Freund's complete adjuvant (FCA) were also performed (30). Administration of a sea buckthorn leaf extract reduced both the swelling and accumulation of labeled glutathione (GSH) in areas that are affected by the disease. The extract also inhibited lymphocyte proliferation, which suggests that it has a limiting effect on inflammation (30). Moreover, as an in vitro test demonstrated, these leaf extracts show no negative effect on the viability of murine macrophages in test with 3-(4,5-dimethylthiazol-2-yl)-2,5-diphenyltetrazolium bromide (MTT) (29).

Sea buckthorn seed oil has also been shown to possess anti-inflammatory activity in the case of peptic ulcer disease, in both humans and horses. However, no changes in the $\mathrm{pH}$ of the gastric juice during oil treatment were observed $(31,32)$.

\section{Protective and anticarcinogenic properties}

It has been demonstrated that an ethanolic extract of whole sea buckthorn fruits in an RH-3 drug preparation significantly reduced the mortality of mice who were exposed to a lethal dose of gamma radiation (33). The administration of this

Table 7. Amino acid content in sea buckthorn pulp juice (20).

\begin{tabular}{|c|c|}
\hline Amino acids & $\%$, (of total amino acid content) \\
\hline Asparagine & 10.92 \\
\hline Serine & 4.86 \\
\hline Glutamine & 22.51 \\
\hline Glycine & 3.86 \\
\hline Alanine & 3.87 \\
\hline Cysteine & 0.91 \\
\hline Valine & 4.77 \\
\hline Tyrosine & 2.47 \\
\hline Isoleucine & 4.01 \\
\hline Methionine & 0.9 \\
\hline Proline & 5.87 \\
\hline Phenylalanine & 2.74 \\
\hline Histidine & 2.47 \\
\hline Lysine & 4.38 \\
\hline Threonine & 2.43 \\
\hline Leucine & 6.9 \\
\hline Arginine & 15.12 \\
\hline
\end{tabular}

Table 8. Comparison of phenolic compounds in extracts from different parts of sea buckthorn (Soxhlet extract) (23).

\begin{tabular}{|c|c|c|c|c|c|c|c|}
\hline \multirow[t]{2}{*}{ Part of plant } & $\mathrm{RT}$ & $\mathrm{QC}-3-O-\mathrm{G}$ & $\mathrm{QE}$ & MY & KA & IS & $\begin{array}{c}\text { Total content } \\
\text { of phenolics } \\
\text { compounds }\end{array}$ \\
\hline & \multicolumn{7}{|c|}{$(\mu \mathrm{g} / \mathrm{g}$ dried material $)$} \\
\hline Leaves & 313.8 & 280.8 & - & 136.8 & 45.8 & 120.0 & 897.2 \\
\hline Seeds & - & 23.9 & 22.9 & 1.26 & - & 2.22 & 50.28 \\
\hline Pulp & 300.2 & 194.7 & - & 50.1 & 12.61 & 61.5 & 619.11 \\
\hline Whole fruits & 136 & 108.2 & - & 17.3 & 3.71 & 41.2 & 306.41 \\
\hline
\end{tabular}

Abbreviations: RT-rutin, QC-3-O-G-quercitin-3-O-galactoside, QE-quercetin, MY-myricetin, KA-kaempferol, IS-isorhamnetin 
preparation improved the parameters of peripheral blood, such as hemoglobin and lymphocytes levels, in comparison to blood parameters for animals exposed for irradiation (34).

Studies have been carried out to evaluate the effects of sea buckthorn extracts that are rich in proanthocyanidins (SPB-PE) on the variation in the type and quantity of stem cells in the blood. The administration of SPB-PE caused changes in some stem cells, i.e., CD45dim CD34+ CD309-, CD45dim CD34+ CD309+, and CD45- CD31+ CD309+, but no significant changes were observed in other stem cells, which suggested that the extract triggered cell-specific actions (35).

The adaptogenic activity of sea buckthorn leaves was tested on laboratory rats. Stress was induced on rats by lowering their body temperature to induce hypoxia and immobilization. With a decrease in GSH, GST, and CAT activity, an increase in SOD activity was observed in nonexposed rats treated with an extract of sea buckthorn. However, no changes in malondialdehyde (MDA) levels were observed (36). An administration of sea buckthorn extracts for $30 \mathrm{~min}$ before exposition on stressful factors caused an increase in the activities of GSH, CAT, GST, and SOD, and decreased MDA and glucose levels in rat blood. Moreover, treatments with sea buckthorn leaf extract induced a decline in free fatty acid (FFA) levels, and a decrease of blood lactate dehydrogenase (LDA), which indicates that free fatty acids were being more effectively used in the energetic processes of the body. This data suggested the possibility of using sea buckthorn extracts for cumulative extreme conditions, e.g., activities in high-altitude environments such as mountain climbing (36). Studies have shown that sea buckthorn extracts stimulate reactions for both anaerobic and aerobic metabolism (37).

Polyphenols isolated from sea buckthorn roots, such as syringetin, isorhamnetin, and pentamethylquercetin show an ability to inhibit tumor cell proliferation, and quercetin and myricetin induce the apoptosis of these cells. Since this effect has not been observed in healthy cells, this suggests a specific effect of these compounds on cancer cells (32). Moreover, the administration of an alcohol extract from sea buckthorn branches inhibits the development of skin cancer processes in mice (38).

\section{Metabolism regulation and cardioprotective prop- erties}

Extracts from sea buckthorn leaves act as hepatoprotectives, which are manifested by the sta- bilization of bilirubin, alanine aminotransferase (ALT), aspartate aminotransferase (AST), and $\gamma$ glutamyltransferase (GGT) in the serum of rats administered with $\mathrm{CCl}_{4}$ (6). Sea buckthorn extract also shows a tendency to inhibit $\alpha$-glucosidase activity, which is responsible for carbohydrate metabolism in the gastrointestinal tract (5).

Mice administered with prepared residues from sea buckthorn seeds that are rich in flavonoids showed positive influences with regard to glucose and fat homeostasis. A decrease in total cholesterol, triglycerides, and serum glucose levels was observed. The administration of a sea buckthorn preparation also led to the reduction of liver mass and the amount of fat that was located in the epididymis area, which had initially been incurred from a high-fat diet. It can be assumed that sea buckthorn extracts and seed residues that are rich in flavonoids can prevent or reduce abdominal obesity, by reducing the amount of fat that is stored in the body (39). For obese men, it was also observed that the addition of sea buckthorn fruit to meals had a significant effect on blood insulin levels that were measured 30 and $45 \mathrm{~min}$ after a meal and that the maximum level of blood insulin decreased (40).

In addition, sea buckthorn seed oil administration to rabbits decreased the cholesterol level and the low-density lipoprotein (LDL) to high-density lipoprotein (HDL) ratio in their blood plasma. This was accompanied by a reduced platelet aggregation, which leads us to believe that sea buckthorn oil may have a beneficial effect on the prevention and treatment of atherosclerosis (41). The administration of a flavonoid-rich sea buckthorn fruit-based preparation also decreased platelet aggregation. The sea buckthorn preparations (different extracts) lengthened the blood clotting time, making it possible to conclude that such preparations will be beneficial in the treatment of thrombosis conditions $(28,42)$. In addition, this formulation protects low-density cholesterol from oxidation, which can also have a positive effect when treating atherosclerosis and vascular thrombosis (42).

Seed oil from sea buckthorn also influences the aortic diastolic response that is caused by acetylcholine (ACh). The administration of oil to rats caused a significant improvement in aortic diastolic responses to control subjects over the entire range of ACh concentrations tested. Improvements in this parameter were also observed to some extent in acetylcholine concentrations in individuals with induced hypercholesterolemia, for which the aortic diastolic response was close to the control group level. It can be assumed that people suffering from 
hypertension who take sea buckthorn seed oil will obtain beneficial effects on the effectiveness of blood pressure-reducing preparations (43).

The influence of sea buckthorn seed oil on the reduction of hypertension and cholesterol levels in the blood was studied in a group of volunteers. Monthly supplementations with sea buckthorn oil capsules improved the analyzed parameters in healthy and hypertensive patients, and those suffering from hypertension and hypercholesterolemia, compared to the control group, which received a placebo. Reductions in the total blood cholesterol content, LDL/HDL and oxy-LDL/HDL ratios, and triglyceride and homocysteine levels were observed in the sea buckthorn treatment groups, as well as a significant increase in total antioxidant content. During the experiment, no changes in body mass index were observed in any of the studied groups. The observed effects were attributed to the presence of significant amounts of omega-3, omega- 6 , and omega- 9 acids, and a high content of natural antioxidants, mainly vitamin $E$ and $\beta$-carotene (44).

In studies on the content of individual fatty acids in the liver and fat tissues of Wistar rats administered sea buckthorn pulp oil, soybean oil, or pork lard as fat sources, the administration of sea buckthorn oil resulted in the highest content of tocopherols, $\beta$-carotene (which was converted to retinol) and fatty acids, compared to the other two preparations. An increase in tissue retinol content was also observed. The contents of palmitoleic, vaccenic, and palmitic acids also increased in relation to other fatty acids; this occurred both in the liver itself and in fatty tissues. This change was also observed to be accompanied by decreases in the stearic and oleic acid contents, in both tissues. The $\alpha$-tocopherol content in sea buckthorn oil was almost the same as that of soybean oil, and the difference in content compared to lard was not significant (45).

\section{Antibacterial and antifungal properties}

In addition to their antioxidant effects, sea buckthorn extracts also have the ability to inhibit the growth of bacteria and fungi, such as Bacillus cereus, Pseudomonas aeruginosa, Staphylococcus aureus, Escherichia coli $(25,46)$, Enterococcus faecalis (46) and Enterococcus durams (25), and Candida albicans yeast (25). As with the antioxidant properties of sea buckthorn, its observed antibacterial and antifungal activities are attributed to the phenolic compounds that are contained in the different parts of the plant. These properties explain the traditional use of sea buckthorn in the treatment of difficult-to-heal wounds $(25,46)$.

\section{Skin effects}

Historically, sea buckthorn has been used to treat skin wounds that are caused by burns and ulcers. The use of preparations that are based on sea buckthorn accelerated the healing process, and also supported the creation of new capillaries at the wounded site (47).

The effect of sea buckthorn on skin wounds has been confirmed in rat studies. It was observed that direct applications of sea buckthorn seed oil on the skin caused a significant decrease in burns surface area. Also, an increase in glutathione content was found in tissue samples from rats treated with seed extract. It was observed that the oil treatments more effectively increased blood vessel network density and the thickness of the dermis, compared to silver sulfadiazine treatments. After an application of sea buckthorn seed extract, the overexpression of metalloproteinases of the extracellular matrix (MMP-2 and MMP-9) in tissues that participate in the process of the regulation of repair processes (elimination of damaged proteins, regulation of the activity of some growth factors) of wound healing, especially in the phase of tissue remodeling, was also shown $(48,49)$.

It was also shown that local applications of sea buckthorn oil-based cream led to a reduction in skin lesions in rats in the course of atopic dermatitis (AD) caused by 2,4-dinitrochlorobenzene (DNCB). This method of administration of sea buckthorn did not result in a reduction of body weight, as a side effect of traditional AD therapy. A lower weight of spleen and lymph nodes was observed in individuals that were treated with sea buckthorn oil cream, compared to the negative control. At the same time, the effect of sea buckthorn oil on keratinocytes (HaCaT) activated with interferon $\gamma($ IFN- $\gamma$ ) and tumor necrosis factor $\alpha$ (TNF $\alpha$ ) was checked. IFN- $\gamma / \mathrm{TNF}-\alpha$ was applied to these cells, to determine the levels of nuclear factor kappa B (NF-ęB) and signal transducer and activator of transcription 1 (STAT1) proteins. It was noted that sea buckthorn oil reduces the activation of NF-ęB and STAT1 by IFN- $\gamma /$ TNF- $\alpha$, compared to the negative control (50). In addition, a protective effect of sea buckthorn seed oil on keratinocytes and fibroblasts exposed to UVA and UVB radiation was shown. It was observed that oil administration prevents redox imbalances and enhanced lipid metabolism. This data suggested that sea buckthorn seed oil is a promising candidate as a natural skin photo-protector (51).

Moreover, the composition of fatty acids in the skin and plasma of patients with AD before treatment with sea buckthorn oil, and after four months 
of treatment, were studied. In patients who took capsules containing oil from the flesh, an increase in stearic acid, arachidonic acid (AA), and docosahexaenoic acid (DHA) was observed in skin glycerophospholipids. Moreover, a decrease in the amounts of palmitic and oleic acids, and a decrease in the amount of linoleic (LA) and $\alpha$-linolenic (ALA) acids in blood plasma was observed. However, in patients taking sea buckthorn seed oil capsules, a decrease in the contents of palmitic acid, oleic acid, and DHA in skin glycerophospholipids was observed. At the same time, an increase in the amounts of LA and stearic acids in skin glycerophospholipids, and an increase in the amount of LA and ALA acids in plasma were observed (13). Changes in the contents of fatty acids are related to the roles and actions of individual compounds. Linoleic acid protects against an excessive loss of water through the skin and prevents its exfoliation. It has been observed that the level of 13-hydroxy9,11-octadecadienoic acid (13-HODE), formed by the action of 15-lipooxygenase (15-LO) on linoleic acid, may be closely related to the proliferation of epidermal cells (a low content of 13-HODE and an increased activity of protein kinases $\mathrm{C}$ alfa and beta (PKC $\alpha$ and $\mathrm{PKC} \beta$ ) in response to the hyperproliferation of keratinocytes; at a local increase in the contents of 13-HODE, excessive cell division was inhibited, and the activities of protein kinases were reduced.) Moreover, linoleic and arachidonic acids are precursors in the biosynthesis of leukotrienes (lipids that are involved in inflammatory states and immunological responses) and prostaglandins (which modulates the courses of physiological processes and inflammatory states). Additionally, docosahexaenoic acid is converted by 15-lipooxygenase to 17-hydroxydocosahexaenoic acid (17HDoHE), which has an anti-inflammatory effect. This effect on fatty acids suggests that enriching the diet with unsaturated fatty acids will reduce inflammation in people who are affected by skin diseases (52).

The effects of sea buckthorn-based cream on the skin of hyperpigmented patients have been tested. It was observed that the level of melanin decreased after three months of regular use of the cream. This effect was attributed to the inhibitory effect of sea buckthorn extracts on tyrosinase, which, by limiting tyrosine conversion to melanin, leads to a reduction in the amount of pigment in the skin (53).

It was observed that both the regular use of sea buckthorn-based cream and the consumption of capsules containing sea buckthorn oil have a positive effect on the visual appearance of the skin. Using non-invasive techniques, characteristics such as elasticity, hydration, brightness, thickness, and the roughness of the skin, before and after one month and three months, were checked. It was observed that with the addition of four capsules containing 0.5 $\mathrm{g}$ of sea buckthorn oil each, the roughness of the skin was reduced, which suggests an anti-wrinkle effect. The cream was used to increase skin thickness, which suggests an increase in collagen synthesis and positive structural changes. Additionally, during the application of both the cream and oil capsules, a significant improvement in hydration and skin elasticity was observed (54). It was also found that supplementation with sea buckthorn oil capsules has a positive effect on dry-eye symptoms in patients aged 20-75 years. It was observed that with the regular use of capsules, redness and burning decreased (55).

\section{CONCLUSION}

The rich composition of fruits, seeds and leaves of sea-buckthorn makes it the subject of many studies on the possibility of using extracts/oil of this plant as constituents of medicinal products. The tests, both in vitro and in vivo, using sea buckthorn, confirm its significant antioxidant, antibacterial and anti-inflammatory effects. Due to the high content of antioxidant compounds (mainly flavonoids) in extracts from various parts of sea buckthorn, plant preparations can be used as a hepatoprotective and antineoplastic agent. In addition, oral administration of sea buckthorn oil has been shown to reduce the side effects of cancer treatment. It is also possible to use sea buckthorn preparations as a natural agent that protects the skin against UV radiation, as well as to treat skin wounds healing. There are also presented the potential applications of sea buckthorn in the treatment of blood vessel thrombosis, atherosclerosis and type 2 diabetes. In conclusion, it can be concluded that the variety of ingredients contained in sea buckthorn provides a real opportunity to use this plant in the treatment of many diseases.

\section{Conflict of interest}

The authors declare no conflicts of interest.

\section{REFERENCES}

1. Gupta A., Suryakumar G.: J. Ethnopharmacol. 138, 268 (2011). 
2. Kumar R., Kumar G.P., Chaurasia O. P., Singh S.B.: Res. J. Med. Plant. 5, 491 (2011).

3. Olas B.: J. Ethnopharmacol. 213, 183 (2018).

4. Zeb A.: Sea Buckthorn (Hippophae rhamnoides L. ssp. turkestanica) Seeds: Chemical, and Physicochemical Properties, pp. 1003-1010, Academic Press, San Diego 2011.

5. Myong-Jo K., Ju-Sung K., Yong-Soo K., YeoJin S.: J. Agric. Food Chem. 59, 138 (2011).

6. Kumar M.S.Y., Maheshwari D.T., Verma S.K., Singh V.K., Singh S.N.: Food Chem. Toxicol. 49, 2422 (2011).

7. Kumar M.S.Y., Dutta R., Prasad D., Mishra K.: Food Chem. 127, 1309 (2011).

8. Yue X-F., Shang X., Zhang Z-J., Zhang Y-N.: J. Food Drug Anal. 25, 327 (2017).

9. Guo R.X., Guo X., Li T., Fu X., Liu R.H.: Food Chem. 221, 997 (2016).

10. Zadernowski R., Naczk M., Czaplicki S., Rubinskiene M., Szalkiewicz M.: J. Am. Oil Chem. Soc. 82, 175 (2005).

11. Cenkowski S., Yakimishen R., Przybylski R., Muir W.E.: Can. Biosyst. Eng. 48, 3.9 (2006).

12. Abid H., Hussain A., Ali S.: J. Chem. Soc. Pak. 29, 256 (2007).

13. Yang B., Kalimo K.O., Tahvonen R.L., Mattila L.M., Katajisto J.K., Kallio H.P.: J. Nutr. Biochem. 11, 338 (2000).

14. Korekar G., Dolkar P., Singh H., Srivastava R. B., Stobdan T.: LWT-Food Sci. Technol. 55 157 (2014).

15. Zheng J., Kallio H., Linderborg K., Yang B.: Food Res. Int. 44, 2018 (2011).

16. Eccleston C., Baoru Y., Tahvonen R., Kallio H., Rimbach G.H., Minihene A.M.: J. Nutr. Biochem. 13, 346 (2002).

17. Ercisil S., Orhan E., Ozdemir O., Sengul M.: Sci. Hort. 115, 27 (2007).

18. Bal L.M., Meda V., Naik S.N., Satya S.: Food Res. Int. 44, 1718 (2011).

19. Ursache F.M., Ghinea I.O., Turturicǎ M., Aprodu I., Râpeanu G., Stănciuc N.: Food Chem. 233, 442 (2017).

20. Teleszko M., Wojdyło A., Rudzińska M., Oszmiański J., Golis T.: J. Agric. Food Chem. 634120 (2015).

21. Uransanaa M., Gerel D., Jamyansan Y., Dash T.: Mong. J. Biol. Sci. 1, 85 (2003)

22. Christaki E.: Food Public Health. 2, 69 (2012).

23. Seglina D., Karklina D., Ruisa S., Krasnova I.: J. Fruit Ornam. Plant Res. 14, 257 (2006).

24. Sharma U.K., Sharma K., Sharma N., Sharma A., Singh H.P., Sinha A.K.: J. Agric. Food Chem. 56, 374 (2008).
25. Michel T., Destandau E., Le Flochc G., Lucchesi M. E., Elfakir C.: Food Chem. 131, 754 (2012).

26. Yasukawa K., Kitanaka S., Kawata K., Goto K.: Fitoterapia 80, 164 (2009).

27. Skalski B., Kontek B., Lis B., Olas B., Grabarczyk Ł. et al.: BMC Complement. Altern. Med. 19, 148 (2019).

28. Olas B., Żuchowski J., Lis B., Skalski B., Kontek B. et al.: Food Chem. 247, 39 (2018).

29. Padwad Y., Ganju L., Jain M., Chanda S., Karan D. et al.: Int. Immunopharmacol. 6, 46 (2006).

30. Ganju L., Padwad Y., Singh R., Karan D., Chanda S. et al.: Int. Immunopharmacol. 5, 1675 (2005).

31. Xing J., Yang B., Dong Y., Wang B., Wang J., Kallio H.P.: Fitoterapia 73, 644 (2002).

32. Huff N.K., Auer A.D., Garza F., Keowen M.L., Kearney M.T. et al.: J. Vet. Intern. Med. 26, 1186 (2012).

33. Mishra K.P., Chanda S., Karan D., Ganju L., Sawhney R.C.: Phytother. Res. 22, 1490 (2008).

34. Goel H.C., Prasad J., Singh S., Sagar R.K., Kumar I.P., Sinha A.K.: Phytomedicine 9, 15 (2002).

35. Drapeau C., Benson K.F., Jensen G.S.: Clin. Interv. Aging 14, 253 (2019).

36. Saggu S., Kumar R.: Phytomedicine 15, 437 (2008).

37. Saggu S., Kumar R.: Food Chem. Toxicol. 45, 2426 (2007).

38. Yasukawa K., Kitanaka S., Kawata K., Goto K.: Fitoterapia 80, 164 (2009).

39. Wang J., Zhang W., Zhu D., Zhu X., Pang X., Qu W.: J. Sci. Food Agric. 91, 1446 (2011).

40. Mortensen M.W., Spagner C., Cuparencu C., Astrup A., Raben A., Dragsted L.O.: Eur. J. Nutr. 57, 2827 (2018).

41. Xu Y-J., Kaur M., Dhillon R.S., Tappia P.S., Dhalla N.S.: J. Funct. Foods. 3, 2 (2011).

42. Cheng J., Kondo K., Suzuki Y., Ikeda Y., Meng X., Umemura K.: Life Sci. 72, 2263 (2003).

43. Basu M., Prasad R., Jayamurthy P., Pal K., Arumughan C., Sawhney R.C.: Phytomedicine 14, 770 (2007).

44. Vashishtha V., Barhwal K., Kumar A., Hota S.K., Chaurasia O.P., Kumar B.: Clin. Nutr. 36, 1231 (2017).

45. Czaplicki S., Ogrodowska D., Zadernowski R., Konopka I.: Plant Food Hum. Nutr. 72, 198 (2017).

46. Upadhyay N.K., Kumar M.S.Y., Gupta A.: Food Chem. Toxicol. 48, 3443 (2010). 
47. Gendaszewska-Darmach E., Majewska I.: Acta Biochim. Pol. 58, 449 (2011).

48. Upadhyay N.K., Kumar R., Mandotra S.K., Meena R.N., Siddiqui M.S. et al.: Food Chem. Toxicol. 47, 1146 (2009).

49. Upadhyay N.K., Kumar R., Siddiqui M.S., Gupta A.: Evid. Based Complement. Alternat. Med. 2011 (2011).

50. Hou D.D., Di Z.H., Qi R.Q., Wang H.X., Zheng S. et al.: Skin Pharmacol. Physiol. 30, 268 (2017).

51. Gęgotek A., Jastrząb A., Jarocka-Karpowicz I., Muszyńska M., Skrzydlewska E.: Antioxidants 7, 110 (2018).
52. Ziboh V.A.: Lipids 31, S249 (1996).

53. Khan B.A., Akhtar N., Hussain I., Abbas K.A., Rasul A.: Adv. Dermatol. Allergol. 30, 226 (2013).

54. Yang B., Bonfigli A., Pagani V., Isohanni T., von-Knorring A. et al.: J. Appl. Cosmetol. 27, 13 (2009).

55. Larmo P.S., Ja“rvinen R.L., Seta“la“ N.L., Yang B., Viitanen M.H. et al.: J. Nutr. 140, 1462 (2010).

Received: 17.06.2019 